\title{
AN INSTITUTIONAL ANALYSIS OF THE GROWTH OF EXECUTIVE REMUNERATION
}

\section{David Peetz}

Griffith University

forthcoming (in a corrected and copy-edited form, without the errors in this document) as 'An institutional analysis of the growth of executive remuneration', Journal of Industrial Relations, 57(5), November 2015. DOI: 10.1177/0022185615590903

\begin{abstract}
This article develops a framework for understanding growth in executive remuneration and its increasing divergence from average earnings since a 1980s turning point, drawing on studies from a range of countries but with a special focus on Australian evidence. This framework emphasises the central roles played by: company size, to which power is intrinsically related; the distinct, asymmetric nature of the 'bargaining' relationship in executive labour markets; and institutions that reflect seven rules. A corporation's status depends in part on its CEO's status and pay. CEOs' ability to extract rents is influenced by their social capital. CEO pay is heavily influenced by relative pay deprivation. Institutions emerge to facilitate dual-asymmetric pattern bargaining. The incentive structure of executive pay adjusts over time to minimise downside risk, justify high growth and deflect shareholder concerns. Different norms shape pay in different segments, though crosssegment references will be made to justify increases. Finally, CEOs' ability to ratchet pay upwards is contested, leading to cycles of asymmetries reflecting the social, political and economic climate and balance of power.
\end{abstract}




\section{AN INSTITUTIONAL ANALYSIS OF THE GROWTH OF EXECUTIVE REMUNERATION}

\section{The problem of executive remuneration}

Across Europe, the US and Australia, four fifths of people believe business leaders in their countries are overpaid (Harris Interactive, 2009; see also Blitz, 2003) and/or that executive salaries should be capped (Colmar Brunton, 2009; Ferguson, 2009; Essential Research, 2010). Admissions from directors and executives reinforce this. A 2005 survey cosponsored by the Australian Institute of Company Directors (AICD) showed over two thirds of directors considered chief executive officers (CEOs) were overpaid by between $20 \%$ and 50\% - notwithstanding that boards of directors set CEO pay (Buffini and Pheasant, 2005). In-depth interviews with non-executive directors found 'almost all express a level of concern', evoking comments such as CEO pay 'needs to be capped so that it doesn't become obscene’ and 'I don’t think any individual is worth that much' (O'Neill, Graham, 2007). In Britain, the head of the Institute of Directors remarked the 'current rate of executive pay is unsustainable’ (Mitchell, 2011). Several global business leaders (quoted in Mann, 2011) criticised ‘excessive compensation', seen as ‘intrinsically unjustified’. Paul Anderson, then retiring CEO of BHP Billiton, remarked 'CEO compensation is totally out of control...[T]here's no way to justify the incredible compensation' (Correy, 2003). The retiring global CEO of Royal Dutch Shell conceded 'if I had been paid 50\% more, I would not have done it better. If I had been paid 50\% less, then I would not have done it worse' (Hoyos and Steen, 2009). 
Objective factor justify this disaffection. From the mid 1980s real executive salaries grew substantially faster than average real wages. Yet this difference in growth rates has not always existed. Australian series on executive remuneration and average earnings tracked each other fairly closely through the 1970s and early 1980s. From 1985 they diverged. Real CEO pay grew by nearly five times during the period 1971-2008, whereas real average weekly earnings grew just over 11/2 times (Peetz, 2009, calculated from Noble Lowndes Cullen Egan Dell, 1994; Shields, O'Donnell and O'Brien, 2003; Egan, 2009). CEO pay is a significant factor explaining the rise in top income earners' share of national income (Atkinson and Leigh, 2007). This increase in top income shares is itself a historically recent phenomenon: from 1920 to the early 1980s, top income earners’ share generally declined (ibid).

Australia was not unique. The US ratio of senior executive remuneration to average earnings was relatively stable through the post war period to the early 1970s (indeed declining by $13 \%$ between the 1950s and 1970s), but then started to grow, accelerating significantly from the mid 1980s. From the 1980s to $2000-2003$, the ratio grew by $560 \%$ (Frydman and Saks, 2005). Between 1980 and 2003, the richest 10\% of Americans obtained 91\% of growth in national income (Economic Policy Institute, 2010). In the UK, 'starting in the early 1980s', relative executive pay grew 'exponentially'; the ratio to workers’ pay quadrupled over 30 years (High Pay Commission, 2011, 16-17).

This paper develops a framework for understanding inflation in executive remuneration since the turning point of the early 1980s and growing divergence from average earnings. It 
has three key elements, the central roles played by: company size; overlapping identities; and formal and informal institutions. We identify seven behavioural norms underpinning CEO labour market institutions. Some of the elements of this framework are referred to in other analyses but none have brought them together in this way. While the inspiration came from Australian firms, and we draw upon studies from a range of countries but especially Australian evidence, it is an analytic framework that can be applied more broadly as it takes account of contextual differences.

This framework challenges that posed by agency theory (extensively critiqued by Thornthwaite, 2010). Debate in executive remuneration research often concerns whether there is a causal, positive link from corporate performance to remuneration, and agency theory has provided the major theoretical framework (Jensen and Murphy, 1990), sometimes contrasted to earlier managerialist theory (Berle and Means, 1932; Herman, 1981). Agency theorists indicate CEOs have different interests to shareholders and will use information asymmetry between themselves and shareholders to their advantage, so their policy questions concern monitoring or inventive structures to align the interests of shareholders and CEOs. Evidence suggests the link between pay and performance is often either negligible or negative (Firth, Tan and Tang, 1999; Shields, O’Donnell \& O’Brien 2003, 2004; Yernack, 2005; Berrone and Otten, 2008; RiskMetrics Australia, 2009), though there is also some evidence for a weak, positive link, at least on occasion, with some studies finding a link only in certain sub-periods or circumstances within their study (Matolcsy, 2000; Holland, Dowling and Innes, 2001; Sung and Swan, 2009; Tosi, Werner, Katz and Gomez-Mejia, 2000; Tomar and Korla, 2011; Doucouliagos, Graham and Haman, 2012). So executive pay practices have not yet solved the agency problem. 
However, the issue most bothering the public is not the misalignment of CEOs with shareholders but the misalignment of CEOs with society. The agency debate does not address the recent divergence between CEOs and average workers. Even if a link existed between CEO pay and performance, this should not in itself create the recent divergence, unless it generated a substantial improvement in performance. The evidence is against such an improvement: Australian national productivity growth has been lower since the mid 1980s than in the 1960s and 1970s (eg Quiggin, 2006) and G7 nations’ growth in GDP per hour was higher in the 1970s than from the 1980s onwards (OECD productivity database). An alternative argument might be that profits, not productivity, are what counts. The Productivity Commission (PC) (Productivity Commission, 2009:xxiii,73) argued that 'executive remuneration has grown at similar rates to company performance' as evidenced by its tracking the Australian Sock Exchange (ASX) accumulation index. The ASX200 measures the cumulative value an investor would have after year 1 if they invested in Australia’s 200 largest listed firms and took no dividends as income, instead reinvesting all dividends in the same companies. The PC was comparing chalk and cheese. Rather than just representing growth in income, the ASX accumulation index signifies the combined growth of accumulated, fully reinvested income plus the returns from its full reinvestment. The PC confused income with an imaginary concept of accumulated wealth (it being unrealistic to assume no personal income is consumed and it is all, instead, invested). From a national welfare perspective, a more valid reference point is national productivity. Higher profits may only signify a shift from labour to capital; an increase in national welfare would require growth in productivity.

There has been a major change in composition of CEO pay in Australia (O’Neill and Berry, 2002) and overseas (Pratt, 1996) towards greater use of 'incentive' pay. Agency theory 
predicts 'incentives' will align the interests of CEOs and shareholders on profitability; but it does not explain why CEO pay has grown so rapidly. If only realignment of interests was relevant, 'base’ pay would reduce as ‘incentive’ pay increased, and total CEO pay on average would change little. Instead the growth of incentives has accompanied and factored into the growth of total CEO pay (Pratt, 1996; O'Neill, G and Berry, 2002). Agency theory's emphasis on divergent interests overlooks the role played by overlapping identities and social milieus of boards and CEOs, in contrast to conflicting interests and milieus in determining ordinary workers’ wages.

\section{Size and overlapping identities}

The first two elements of this framework are size, widely acknowledged in research, and overlapping identities, which is less acknowledged.

\section{Size}

Large firms have greater power in product markets, supply chains and influencing governments. Executives of larger corporations command more resources - as others depend on those, the power of the resource controllers grows (Nienhueser, 2008). They have greater opportunities for 'value skimming', benefiting from 'their proximity to large flows of revenue and fees'; so high executive pay reflects 'the advantages of position' (Erturk, Froud, Johal, Leaver and Williams, 2007:65). In many studies firm size is the largest determinant of executive remuneration (Marris, 1964 cited in Francis, 1980; Firth, M, Tan and Tang, 1999; Tosi et al., 2000; Frydman and Saks, 2005; Productivity Commission, 2009; Hunter, 2011). With concentrating of ownership in advanced capitalist societies, including Australia (Peetz and Murray, 2012), size of key corporations has grown. The size-pay effect is often 
attributed to greater task complexity (eg Tomar and Korla, 2011), but this view was challenged by interviewees in a study of New Zealand CEOs (Crombie, 2010). If size effects on CEO pay reflected not power but complexity, then mergers and acquisitions would benefit both shareholders and CEOs of acquiring firms; yet evidence suggests often none of the gains accrued to acquiring firms' shareholders, while their CEOs benefited extensively (Bliss and Rosen, 2001; Haleblian, Devers, McNamara, Carpenter and Davison, 2009). While larger companies also pay other employees higher wages, that is sometimes explained by workplace size or human capital effects (Kruse, 1992; Reilly, 1995) and, regardless, is a much smaller effect than the size-impact on CEO pay (ibid; Brown and Medoff, 1989, cf Productivity Commission, 2009:xviii) suggesting CEO power over resources, rather than corporate capacity to pay, is key in the size effect.

\section{Overlapping identities}

The second key element is the asymmetric nature of the 'bargaining' relationship. While agency writers focus on divergent interests of shareholders and executives, we pay attention to overlapping interests, or at least identities and social milieus, of boards and CEOs. One advocate for high CEO pay points to the explanatory failure of the agency problem, as 'a private equity group with a controlling interest in a firm does not face this supposed principal-agent problem...[yet they] also pay their chief executives similarly high compensation’ (Mankiw, 2014). Rather than having opposing identities to executives, the members of boards or committees setting CEO pay are from the same social milieu with broadly comparable interests -- sometimes CEOs themselves -- and typically they obtain status and reputation from executive remuneration. The largest shareholders are commonly other corporations, usually finance capital (Peetz and Murray, 2012), whose executives’ own remuneration might be threatened if executive remuneration was moderated across 
companies they owned. The market is 'distorted' by the power CEOs possess and the absence of genuine opposition of interests that exists elsewhere in the labour market, precluding ‘arms length bargaining’ (Bebchuk and Fried, 2004; Yablon, 2008).

Greater consonance of interests may enhance pay growth. Guest (2010) found UK CEO pay grew faster where executive directors comprised a higher proportion of the board, and the pay-performance nexus fell as the share of executive directors increased. But even nonexecutive directors, typically recruited by the board or CEO, are from the same milieu, so some pay studies show no moderating impact from non-executive directors (Doucouliagos, Graham and Haman, 2012).

\section{Institutions}

'Institutions' refer to 'enduring set[s] of ideas about how to accomplish goals generally recognized as important' (Johnson, 2005). In labour markets for executives and directors, social norms are a critical institution. These norms can be summarised by seven behavioural rules, set out below. The relative space devoted to them here signifies not their relative importance viz-a-viz size and overlapping interests, but simply the number of behavioural rules of interest here.

The role of institutions suggests a labour segmentation approach may also be more useful for understanding CEO pay than classical labour economics. Labour segmentation theory normally focuses on how the demand side of labour markets (the practices of employers) and the supply side (divided by class, gender, race, skill or qualification) interact to create social 
differentiations providing unequal access to employment and income (Rubery, 2005), and shows how, by separating workers into groups with different bargaining power and status, workers with similar productivity are paid differently (Brosnan, 1996). Thus its main emphasis is on disadvantage. However, segmentation also helps create advantage, through the practices of employers in specific institutional contexts.

1 The status of a corporation depends in part on the status and hence pay of its CEO.

Board and remuneration committee members associate status and reputational with CEO pay and perquisites. Status shapes remuneration decisions. As disclosed by the director of the AICD:

it’s quite possible that a bank CEO would do a terrific job on quite a lot less pay, but no bank board is going to want to pay its CEO substantially less than the market norm (Evans quoted in Buffini and Pheasant, 2005).

High pay of CEOs in large corporations has symbolic significance (Tosi and Greckhamer, 2004) and reinforces organisational status. As Warren Buffet (2011) argues, 'No company wants to be in the bottom quartile as far as CEO pay goes'. Firms like to have 'celebrity' CEOs (Vintila, 2006;Krugman, 2002; Macek quoted in Maiden, 2003), and 'celebrity’ status may boost CEO pay (Hayward, Rindova and Pollock, 2004), even though shareholder returns typically decline after a CEO reaches ‘celebrity’ status (Schwab, 2009b; Kahneman, 2011). CEOs may persuade boards to pay above ‘median' CEO salary for reasons of organizational status. External and internal status overlap: Yernack (2006:230) finds a 
strong link between size and CEO access to corporate jets that is 'consistent with the theory that large perks are used to indicate status in large organisations'.

2 The ability of CEOs to extract rents is influenced by their social capital.

Rents are 'the extra returns that firms or individuals obtain due to their positional advantages' (Bebchuk and Fried, 2004:62). CEOs’ connections through positional advantage shape their status with those making remuneration decisions, and reduce the likelihood of adversarial bargaining. Ang, Nagle and Yang (2008) demonstrated CEO compensation includes a 'social circle premium'. Channels of social interactions that shaped these premiums included 'golfing in the same exclusive club, sharing directors who understand the local pay norm and displaying luxury mansions’ (Ang, Nagel and Yang, 2008). Access to corporate jets increases strongly with CEO membership of distant golf clubs (Yernack, 2005). Being a CEO in a company well connected to other company boards significantly increases CEO compensation, by raising remuneration 'expectations' of those involved (Barnes and Guedj 2006).

The importance of social capital is also illustrated by gender dynamics. Women typically are less integrated into ruling class ‘old boys’ networks (Murray, 2006) and this helps explain the substantial gender pay gap amongst executive directors and CEOs in the UK (Kulich, Trojanowski, Ryan, Haslam and Renneboog, 2011) and Australia (Equal Opportunity for Women in the Workplace Agency, 2008; Australian Institute of Management NSW and ACT Limited, 2009). 
Four decades ago Runciman (1972) drew attention to how people compare themselves to others in a 'reference group' occupying a similar economic position. Executives attach great importance to relative pay (Yablon, 2008) and typically believe that they are above average (Kruger and Dunning, 1999; Dierynck and Renders, 2014) and hence deserve to be paid above average. A survey of 2000 managers by Business Week found $84 \%$ of middle managers rated themselves in the top $10 \%$ of performers in the company and this increased to $97 \%$ amongst executives (quoted in Grote, 2011). In this context, 'envy is bigger than greed' (Buffett, 2011).

The influence of 'relative deprivation' leads to the market possessing strong elements of 'pattern bargaining'. However, it has two key asymmetries: a 'pattern' that is asymmetric, based on asymmetric reference points aiming above the mean; and 'bargaining' that is asymmetric, due to ineffective countervailing force at the bargaining table. Hence the process can be described as dual-asymmetric pattern bargaining. Some CEOs disturb relativities in pay, then others use occupational power to attempt to reassert those relativities, imparting an upward bias to aggregate CEO pay unrelated to performance. For ordinary workers, what would be called 'leapfrogging' is prevented by the existence of countervailing forces at the bargaining table. Management (and in Australia, tribunals) consistently resisted employee attempts to raise wages through leapfrogging. No analogous symmetries operate in the executive remuneration market. Others have referred to leapfrogging as the 'domino effect’ (Williams and Crabb, 1995), the Wobegon effect (Davidoff, 2011) (after a mythical 
place where every child is above average) or even the 'Wal King effect' (West, 2011) (after a demonstrative Australian CEO). Corporate claims that executive pay disclosure rules caused excessive pay growth (eg Australian Institute of Company Directors, 2009:11; Business Council of Australia, 2004:11) conceded the relevance of relative pay deprivation.

Highly relevant is a 1992 face-to-face survey of senior executives in 196 Australian private companies with 100 or more employees. It directly asked how CEO pay was determined, providing a rare, frank insight into executive pay determination (Noble Lowndes Cullen Egan Dell 1994; the author commissioned the report and some charts are reproduced in Peetz, 2009). This survey showed the most important factor was 'remuneration market forces' (what other corporations were paying). Advice and data from remuneration consultants was far more important than views of shareholders, board members or industry associations. The consistency of factors driving executive pay since then is suggested in a 2009 'web poll’ by Egan Associates, using quite different questions. This indicated that the three factors 'with the most significant influence on executive pay' were 'company remuneration policies/ competitive positioning', 'market rates' and 'remuneration consultant data’. Although web-based sampling meant the results should be treated cautiously, 'remuneration consultant data' was again far more influential than 'shareholder views', the latter being three times more likely to be rated the 'least significant influence’ (Egan, 2009).

The NLCED survey also asked how companies sought to pitch or 'position' senior executives' pay. Sixty five per cent of companies had a policy 'positioning' their executives’ pay above the median and 92\% claimed to set them around or above the median. Only 2\% aimed to position pay below median. As virtually all firms attempted to position 
themselves impossibly at or above the median, senior executive remuneration would increase even in an environment of zero inflation and zero productivity gains. A similar pattern was seen in the USA at that time (Crystal, 1991). NLCED respondents were also asked about timing. Some 31\% did not rely on current rates but attempted to anticipate the median any time up to twelve months ahead (NLCED 1992). A consequence of this attempt by most firms to catch up and surpass the median is that CEOs in the lower part of the CEO pay distribution record higher growth on average than those in the upper part of the pay distribution, while CEO pay diverges from average weekly earnings: this pattern has been observed in Australia, using five-year periods, over the period 1992-2009 (Doucouliagos, Graham and Haman, 2012:5,25).

In June 2009, Hewitt CSi, a management consultancy, asked 53 medium-large corporations in Australia to indicate where they positioned three components of remuneration for CEOs and Senior Executives. The sample was around a quarter of that in the NLCED survey, but it confirms asymmetry in pitching. The context was very different - there was substantial controversy over CEO pay, an inquiry was underway with the prospect of legislation looming. While very few positioning below the median in either the Hewitt 2009 survey or the NLCED 1992 survey, the asymmetry appeared weaker in 2009: 40\% aimed at fixed remuneration above the median, and 53\% at short-term incentives above the median (Hewitt CSi 2009), compared to 65\% for total pay in 1992 (NLCED 1994). We return to this later.

4 Institutions emerge to facilitate the operation of dual-asymmetric pattern bargaining. 
There is no need for disclosure rules, mentioned above, to enable leapfrogging to occur. Private institutions emerge to spread information mobilising relative pay deprivation. The first institution is pay surveys, creatingh reference points for CEO pay (Bender, 2007:709). They are a recent development: ‘today’s universal practice of setting CEO pay relative to peers was not common in the 1970s...[which] were marked by relatively little compensation consultant activity and scarce objective pay information’ (Nagel, 2007). Faulkender and Yang, (2007:i) found that, when selecting comparators for determining CEO pay, US firms 'forego lower paid potential peers in their same industry in favor of higher paid peers outside of their industry when constructing the peer groups.' Comparative pay of peers was far more important than industry or even size. They concluded selection of relatively highly paid reference points was more common when the CEO was chairman of the board, the firm had greater market share or poorer governance or a particular remuneration consultant was used by the firm (Faulkender and Yang, 2007).

Remuneration consultants are another institution that has gained prominence in the last three decades. After controls, CEO pay is higher in firms that use remuneration consultants (Conyon, 2011). Consultants have an interest in perpetuating growth of executive pay. Setting new benchmarks drives demand for new advice, while recommendations maintaining corporate status facilitate consultant reappointment. The House of Commons Treasury Committee investigating the financial crisis received 'a body of evidence linking remuneration consultants to the upward ratchet of pay of senior executives in the banking sector’ (House of Commons Treasury Committee, 2009:32,33). A leading UK fund manager described them as 'a thoroughly bad influence. They... are only seen to be doing their jobs if remuneration rises' (quoted in Wachman, 2009). One remuneration professional said to Bender (2007:715), 'what you won’t find is we're chasing each other downwards'. 
Another new formal institution is 'remuneration committees' on boards, comprised of persons from similar milieu to directors and the CEO, providing the appearance of independent review (Firth, M., 1980:619). They implement the recommendations of remuneration consultants (after perhaps ‘meet[ing] once per year for 15 minutes’ (Buffett, 2011)). If CEOs help select remuneration committees, or are on compensation committees of companies that in turn are represented on that CEO's own compensation committee, CEO pay is higher (Barnea and Guedj, 2006; Ang, Nagel and Yang, 2008; Conyon, 2011). Thus the Treasury Committee (2009:31) criticised remuneration committees as ‘cosy cartels’ that set 'undemanding targets' while 'ratcheting' pay.

5 The incentive structure of executive pay adjusts over time to minimise downside risk, justify high growth and deflect shareholder concerns.

Incentives, for example share holdings or options, substantially increase the value of CEO remuneration. The inflation of CEO pay has principally occurred through expansion of incentives (Holland et al, 2001; Bender, 2007:715; Productivity Commission, 2009). The higher CEO remuneration in the US than the UK is partly achieved through higher use of incentives (Cosh and Hughes, 1987). Incentives give the appearance of tying executive pay to corporate performance; sometimes a correlation exists, although there is also often a negative relationship (eg the equations in Productivity Commission, 2009:444; see also Thornthwaite 2010). Incentives can also mask the level of pay as 'only relatively few individuals with technical insight are able to understand what an executive is being paid' (High Pay Commission, 2011:41). Incentives are thus an informal institution that emerges to 
facilitate the labour market norms. To insiders, they help respond to the 'strong sense of “felt fair”’ (O’Neill \& Berry 2001:236).

Incentives not only justify growth, they are especially useful in facilitating asymmetric pitching. The Hewitt CSi survey, mentioned above, showed that short-term CEO incentives were more commonly pitching above the median than fixed remuneration. The distribution of long-term CEO incentives was also skewed (Hewitt CSi, 2009). The greater likelihood of pitching incentives at the upper part of the distribution helps explain why short-term incentives became a larger pay component.

However, incentives are only satisfactory to the extent they enable high remuneration packages to be maintained. CEOs resist pay reductions, and so the biggest influence on total pay and incentives is the previous year's payments (Doucouliagos, Graham and Haman, 2012). If incentives point to a reduction in remuneration, then a restructuring of CEO packages (eg to increase the 'base' component or reallocate the balance between short and long term incentives) is often necessary to prevent CEOs from being 'disadvantaged' by circumstances for which they 'could not be blamed', such as a general downturn in the share market (Lazonick and O’Sullivan, 2000:25), so that pay is ‘felt fair’. But Bender (2007) found no instances of CEO pay schemes being amended if they paid in excess of expectations. Her study of executive pay practices in twelve UK companies found all had made changes to pay structures within the previous five years: all but one had a potential to increase the total value of executive pay and none (of the 41 changes) led to a decrease. The most common motivations for change were that schemes were 'below market' or 'not paying enough' (Bender, 2007). 
An Australian study found CEO pay was only correlated with company performance during boom periods; during downturns or flatter economic periods there was 'no relationship between corporate performance and executive remuneration', and during recession on one measure there was a negative relationship (Matolcsy, 2000). A study of US CEO found pay was related to what was euphemistically called 'talent' (enterprise income, after an adjustment for incentives) but this relationship did not hold for periods when enterprise returns were negative; rewards were substantial when enterprise income rose but there were no substantial penalties when enterprise income fell (Sung and Swan, 2009:5-6).

A ratchet effect often means bonuses boost pay during good times, but base levels may then be boosted (or bonuses restructured) to offset losses from incentive forumlae during bad times (eg West, 2008; Schwab, 2009a). A CEO benefiting from rapid short term movement in share prices, and whose overall remuneration is then protected against share price decline by offsetting increases in other components of pay, will experience greater medium term remuneration gains than a similar CEO in a firm with stable share prices. Hence Sung and Schwab (2009) found that asset volatility ('risk') was positively related to CEO pay. Incentives then serve as an informal institution ratcheting up CEO pay. Sung and Swan found no upward trend over 1995-2007 in mean 'talent', but volatility and real CEO pay both trended upwards, in the latter case by $4.4 \%$ per year.

6 Different norms shape pay in different segments, though cross-segment references will be made to justify increases. 
Consistent with labour market segmentation theory (Brosnan, Rea and Wilson, 1995), CEO pay appears to be determined within specific segments operating according to rules distinct from those in other segments and especially from other labour markets (Berrone and Otten, 2008). The general factors inflating US executive remuneration are likely to also inflate Australian executive remuneration, but that does not mean Australian and US CEO pay are determined in a single global labour market. In the NLCED (1992) survey, only 2.5\% admitted 'pay levels overseas' were a 'fairly' or 'very important' source of direction on executive salaries. Later research reinforced that few Australian firms recruited CEOs from overseas (Holland, Dowling and Innes, 2001). If the market for CEOs was internationalizing more than that for other workers, we would expect to see smaller differences in the pay of, say, American and Swedish CEOs, operating in the 'same' labour market, than between American and Swedish restaurant workers, operating in very different labour markets. In 2000-01, CEO pay was 367\% higher in the US than in Sweden, but McDonalds workers' base pay was 8\% lower in the US than in Sweden (Ashenfelter and Jurajda, 2001). Manufacturing workers’ pay shows substantially less cross-country variability than does CEO compensation (Christoffersen and Pavlov, 2003). In 2006, the 20 highest paid US CEOs received three times the average remuneration of the 20 highest paid European CEOs - yet those US companies were smaller than their European counterparts (Anderson, Cavanagh, Collins, Pizzigati and Lapham, 2007). Cross-national differences in CEO pay are 'an expression of deeper social values' (Tosi and Greckhamer, 2004). At least part of the substantial trans-Atlantic difference in CEO pay probably arises from differences in tolerance of inequality and of high CEO pay (including within the ideologies of those in economic elites) (Osberg and Smeeding, 2006; Svallfors, 1993; Austen, 2002) and acceptance of 'market' outcomes (Gerlach, Levine, Stephan and Struck, 2008). While the thinness of the labour market for CEOs is evident (Williams and Crabb, 1995), these norms 
and institutions are significant in both small and large national contexts, but vary between them. Cross-national differences in CEO pay 'do not seem to disappear over time' and persist when other factors, such as firm size, are taken into account (Berrone and Otten, 2008).

That said, mimicking relative pay deprivation, participants and advocates will use international comparisons as a basis for justifying high growth, arguing 'it is an international market that is setting the rate' (BHP Billiton's Argus quoted in Maiden, 2003) so that firms in national economies like Australia's allegedly have to offer higher remuneration to attract or retain CEOs (Productivity Commission, 2009:110-2; O’Neill \& Berry, 2002).

$7 \quad$ The ability of CEOs to ratchet pay upwards is contested.

CEO power to shape pay is (sometimes weakly) constrained by several factors. These include: shareholder activists (including superannuation funds); legislation or other political action seeking to impose limits on CEO excess; and, as hinted above, worker and popular resistance. These all may wax and wane with the political climate, and contribute towards 'cycles of asymmetries', whereby the extent to which firms 'aggressively’ position their CEO pay varies according to how much the context will permit.

While Australian data from both the 1992 NLCED survey and the 2009 Hewitt survey show evidence for dual asymmetric pattern bargaining, the upward bias appears stronger in the 
1992 data than 2009. It seems the 'aggressiveness’ of asymmetric pay pitching strategies (Ryan, 2009) may be related to economic and social conditions facing the corporation, with boom times facilitating more ‘aggressive’ pitching under the name of linking pay to performance, as suggested by the asymmetric link between company performance and pay in boom and decline (Matolcsy, 2000; Sung and Swan, 2009: 5-6). The 'aggressiveness' of pay positioning is also influenced by the social and ideological climate. When there is a surge in community outrage and the threat of legislative action, boards will judge the 'mood' to be against excess, so they (temporarily) lower their positioning. Thus in 2010, following substantial controversy and a Productivity Commission report recommending mild changes to corporate obligations, one analysis of ASX200 companies showed 'boards are bending - if not entirely buckling - by overhauling their incentive schemes, including cutting base pay for some chairmen and chief executives' as 'corporate Australia' engaged in 'a race against time to persuade politicians not to intervene' (McIlwraith, 2010). The subsequent 'two strikes' rule (introduced from 2011, and enabling board spills if annual general meetings voted against remuneration reports in two successive occasions) both altered the balance between activist shareholders and CEOs and changed the environment for pay setting, with some firms forced to 'make a virtue of austerity' (Sexton, 2012) or, in consultants' language, 'adopt a more cautious and thoughtful approach to the structuring of their leadership team’s remuneration' (Egan Associates, 2013:38). This tightening of CEO pay continued until at least 2013 (Australian Council of Superannuation Investors, 2014), which was 'not a result of poor performance' but a 'a genuine tightening of structures and...the overall approach’ (Hagart in Janda, 2014).

The other, longer term contextual factor is the power of labour and the resultant overall regulatory context. The post-War Keynesian compromise was characterized by 'the 
“outrage constraint” that used to limit executive paychecks' (Krugman, 2011a). From the 1980s, changing economic policies associated with financialisation and the move towards neoliberalism marked a shift in power between labour and capital. As a result, CEOs’ capacity to extract rents (Bebchuk and Fried, 2004) increased. In Australia and many other countries, the share of national income going to profits relative to wages increased and continued to rise through the 1990s and 2000s (Australian Bureau of Statistics, 5204.0; Ellis and Smith, 2007). Rents previously shared between labour and capital were appropriated by capital. Although CEO pay appears in national accounts as 'labour income', in substance CEOs have much more in common with capital. As capital's relative power grew, so CEOs exercised their ability to reshape formal and informal institutions influencing executive pay. Financialisation increased the importance of the finance sector, providing executives there with easy access through their intermediary roles to 'value skimming’ (Erturk et al., 2007); the size and visibility of finance executive rewards increased many-fold (Lane, 2010), setting new benchmarks for others to follow. As the 'gap between the rich and the super-rich has grown dramatically’ (Krugman, 2011b), the incentive for executives to aim higher increases.

\section{Conclusions}

Explanation of CEO pay learns more from labour segmentation theory than agency theory or classical labour economics. Segmentation creates advantage for participants in CEO labour markets (contra the disadvantage usually the focus of labour segmentation theory), facilitating growth in real pay well above growth in productivity. Corporate size, overlapping identities and supportive formal and informal institutions help explain the ability 
of CEOs since the 1980s to substantially increase their capture of rents. Formal and informal institutions and norms governing behaviour focus on status, social capital, relative pay deprivation, supportive institutions, pay structures, norms and regulation across time and space, and contestability. Executive pay is characterised by 'dual asymmetric pattern bargaining', with asymmetry in targeting of percentile bands in the executive pay process and in pay setting procedures for CEOs and for workers. Labour negotiates wages with capital, which actively resists labour's claims, but there is no such 'arms length' symmetry in determining executive remuneration. Asymmetry also occurs over time, with CEO pay never returning to its relationship with average earnings through the 1970s or early 1980s, despite several profit crises.

The framework developed here builds on existing research using a variety of techniques and units of analyses, so it does not lend itself to testing in a study using a single unit of analysis (eg the firm). That said, future research could consider: how the pitching of CEO pay (its asymmetry or 'aggressiveness') is influenced and changed over time; why CEO pay seems responsive to performance in some periods but not others; the dynamics of contesting of CEO pay; and policies, including taxation policies, that address not just the divergence between CEO and shareholder interests but the divergence between CEO and societal interests.

The last should take account of inflation of executive remuneration's being fundamentally a phenomenon of class and asymmetries of power between labour and agents of capital. The different methods of pay setting for workers and CEOs reflect core differences in power through a period characterised by 'market liberal' practices. That CEOs are overpaid is 
something, as Leonard Cohen would say, 'everybody knows', including the directors who ultimately decide their pay. Yet firms are unwilling to do anything about it, because to do so would damage internal class relations and organisational status and break the norms of the system. 


\section{References}

Anderson, S, Cavanagh, J, Collins, C, Pizzigati, S \& Lapham, M (2007) Executive Excess 2007: The Staggering Social Cost of U.S. Business Leadership, Institute for Policy Studies, Washington DC.

Ang, J, Nagel, G \& Yang, J (2008) Is there a Social Circle Premium in CEO Compensation? FInancial Management Association European Conference. (SSRN Working Paper). Prague: June. <http://www.fma.org/Texas/Papers/Is_there_a_Social_Circle_Premium_in_CEO_Co mpensation.pdf\%3E.

Ashenfelter, O \& Jurajda, S (2001) Cross-country Comparisons of Wage Rates: The Big Mac Index, Industrial Relations Section, Princeton University, Princeton NJ.

Atkinson, A B \& Leigh, A (2007) 'The Distribution of Top Incomes in Australia' Economic Record, 83 (262) pp. 247-261.

Austen, S (2002) 'An international comparison of attitudes to inequality' International Journal of Social Economics, 29 (3) pp. 218-237.

Australian Bureau of Statistics (5204.0) Australian System of National Accounts. Canberra.

Australian Council of Superannuation Investors (2014) CEO Pay in ASX 200 Companies: 13th Annual ACSI Survey of Chief Executive Remuneration, ACSI, Melbourne.

Australian Institute of Company Directors (2009) Submission by The Australian Institute of Company Directors toThe Productivity Commission in response to theIssues Paper on "Regulation of Director and ExecutiveRemuneration in Australia". AICD. Sydney: 20 May.

Australian Institute of Management NSW and ACT Limited (2009) Report on Gender Pay Differentials. Research and HR Consulting Division, AIM, . Sydney: August.

Barnea, A \& Guedj, I (2006) "But, Mom, all the other kids have one!" - CEO Compensation and Director Networks. Department of Finance, McCombs School of Business, University of Texas. Austin, TX. $<$ http://www.mccombs.utexas.edu/news/Guedj_Barnea.pdf\%3E.

Bebchuk, L \& Fried, J (2004) Pay without Performance: The Unfulfilled Promise of Executive Compensation, Harvard University Press, Boston.

Bender, R (2007) 'Onwards and upwatds: why companies change their executive remuneration schemes, and why this leads to increases in pay' Corporate Governance: An International Review, 15 (5) pp. 709-723.

Berle, A A \& Means, G C (1932) The Modern Corporation and Private Property, Macmillan, New York.

Berrone, P \& Otten, J (2008) 'A global perspective on executive compensation'. in L GomezMejia \& S Werner. Global Compensation: Foundations and Perspectives. Routledge, New York, pp. 113-128.

Bliss, R T \& Rosen, R J (2001) 'CEO compensation and bank mergers' Journal of Financial Economics, 61 (1) pp. 107-138.

Blitz, R (2003) 'Top bosses 'overpaid and mistrusted'.' Financial Times. 30 June.

Brosnan, P (1996) 'Labour Markets and Social Deprivation' Labour and Industry, 7 (2) pp. 3-34.

Brosnan, P, Rea, D \& Wilson, M (1995) 'Labour market segmentation and the state: the New Zealand experience' Cambridge Journal of Economics, 19 (5) pp. 667-696.

Brown, C \& Medoff, J (1989) The employer size wage effect. NBER Working Paper 2870. National Bureau of Economic Research. Cambridge MA. 
Buffett, W. (2011, 22 May) "Salary - Why Are CEOs Paid So Much?" Videos, Articles, and Summaries, Warren Buffett News. Retrieved 16/1/12, from http://warrenbuffettnews.com/warren-buffett-salary-why-are-ceos-paid-so-much/.

Buffini, F \& Pheasant, B (2005) 'By order of the board: CEOs are overpaid.' Australian Financial Review. 8 September.

Business Council of Australia (2004) Executive Remuneration: A Position Paper prepared by the Business Council of Australia, BCA, Melbourne.

Christoffersen, P \& Pavlov, A D (2003) Company Flexibility, the Value of Management and Managerial Compensation SSRN: 20 January. $<$ http://papers.ssrn.com/sol3/papers.cfm?abstract_id=418761\%3E.

Colmar Brunton (2009) Omnibus results, w/c 7-09-09, Executive Pay. Colmar Brunton Sydney.

Conyon, M J (2011) 'Executive Compensation Consultants and CEO Pay' Vanderbilt Law Review, 64 (2) pp. 399-428.

Correy, S (2003) Executive Pay: Curiouser and Curiouser. Background Briefing. ABC Radio National: 20 July. <http://www.abc.net.au/rn/talks/bbing/stories/s907528.htm\%3E.

Cosh, A D \& Hughes, A (1987) 'The anatomy of corporate control: directors, shareholders and executive remuneration in giant US and UK corporations' Cambridge Journal of Economics, 11 pp. 285-313.

Crombie, N A (2010) 'New Zealand's doiscourse on executive remuneration'. 4th New Zealand Management Accounting Conference, Christchurch, Department of Accounting and Information Systems, University of Canterbury.

Crystal, G (1991) In Search of Excess: The Overcompensation of American Executives Norton, New York.

Davidoff, S M (2011) 'Efforts to Rein In Executive Pay Meet With Little Success.' New York Times. 12 July.

Dierynck, B \& Renders, A (2014) 'Disclosure of CEO compensation: Governance, benchmarking or the better-than-average effect?'. Global Engagement and Perspectives: American Accounting Association Annual Meeting, Atlanta, GA, AAA.

Doucouliagos, H, Graham, M \& Haman, J (2012) Dynamics and Convergence in Chief Executive Officer Pay. School Working Paper 2012/3. S o A Faculty of Business and Law, Economics and Finance. Deakin University. Melbourne.

Economic Policy Institute (2010) When income grows, who gains? State of Working America website, calculated from data by Emmanuel Saez, http://www.econ.berkeley.edu/ saez/TabFig2008.xls EPI. Washington DC. $<$ http://www.stateofworkingamerica.org/pages/interactive /?start $=1980 \&$ \&end $=2003>$.

Egan Associates (2013) Discusion Paper - Productivity, Melbourne.

Egan, J (2009) Key Drivers of Executive Pay Decisions. Results of March Web Poll. Sydney. $<$ Error! Hyperlink reference not valid..

Ellis, L \& Smith, K (2007) The global upward trend in the profit share. BIS Working Paper No 231, Bank for International Settlements, Basel.

Equal Opportunity for Women in the Workplace Agency (2008) Gender income distribution of top earners in ASX200 companies: 2006 EOWA census of women in leadership, EOWA, Sydney.

Erturk, I, Froud, J, Johal, S, Leaver, A \& Williams, K (2007) 'Against agency: a positional critique' Economy and Society, 36 (1) pp. 51-77.

Essential Research (2010) Essential Report, Melbourne. 
Faulkender, M \& Yang, J (2007) Inside the Black Box: The Role and Composition of Compensation Peer Groups. SSRN Working Paper: March. $<$ http://ssrn.com/abstract=972197\%3E.

Ferguson, A (2009) 'Executive salary anger puts spotlight on commission report.' Australian. 23 September.

Firth, M (1980) 'Takeovers, shareholder returns and the theory of the firm' Quarterly Journal of Economics pp. 235-260.

Firth, M, Tan, M \& Tang, M (1999) 'The determinants of top management pay' Omega: The International Journal of Management Science, 27 pp. 617-635.

Francis, A (1980) 'Company objectives, managerial motivations and the behaviour of large firms: an empirical test of the theory of 'managerial' capitalism' Cambridge Journal of Economics, 4 pp. 349-361.

Frydman, C \& Saks, R E (2005) Historical Trends in Executive Compensation 1936-2003. ChicagoBooth Economics Workshop. University of Chicago, Booth School of Economics. Chicago: 12 April.

$<$ http://faculty.chicagobooth.edu/workshops/AppliedEcon/archive/pdf/FrydmanSeco ndPaper.pdf\%3E.

Gerlach, K, Levine, D, Stephan, G \& Struck, O (2008) 'Fairness and the employment contract: North American regions versus Germany' Cambridge Journal of Economics, 32 pp. 421-439.

Grote, D (2011) 'Self-assessments can give the wrong impression.' Australian Financial Review. 9 August.

Guest, P M (2010) 'Board structure and executive pay: evidence from the UK' Cambridge Journal of Economics, 34 pp. 1075-1096.

Haleblian, J, Devers, C E, McNamara, G, Carpenter, M A \& Davison, R B (2009) 'Taking Stock of What We Know About Mergers and Acquisitions: A Review and Research Agenda' Journal of Management, 35 pp. 469-502.

Harris Interactive (2009) Six-Country Financial Times/Harris Poll Shows How Badly Economic Crisis Has Hurt Reputation of Business Leaders, FInancial Times / Harris Interactive, London.

$<$ http://www.harrisinteractive.com/news/FTHarrisPoll/HI_FinancialTimes_HarrisPol l_EconomicCrisis_Apr15_09.pdf\%3E.

Hayward, M L A, Rindova, V \& Pollock, T (2004) 'Believing one’s own press: The causes and consequences of CEO celebrity' Strategic Management Journal, 25 pp. 637-653.

Herman, E S (1981) Corporate Control, Corporate Power, Cambridge University Press, Cambridge.

Hewitt CSi (2009) Australoian Top Executive Climate Feature Survey, Hewitt Associates, Sydney.

High Pay Commission (2011) Cheques With Balances: why tackling high pay is in the national interest, High Pay Commission, London.

Holland, P, Dowling, P \& Innes, P (2001) 'CEO compensation in Australia: Is there a relationship between principles, policies and practices?' Asia Pacific Journal of Human Resources, 39 (3) pp. 41-58.

House of Commons Treasury Committee (2009) Banking Crisis: reforming corporate governance and pay in the City. Ninth Report of Session 2008-09, House of Commons: The Stationery Office, London.

$<$ http://www.publications.parliament.uk/pa/cm200809/cmselect/cmtreasy/519/519.pd f\%3E.

Hoyos, C \& Steen, M (2009) 'Shell chief calls for pay reforms.' Financial Times. 8 June. Hunter, T (2011) 'Size does matter, to the CEO.' Sydney Morning Herald. 11 June. 
Janda, M. (2014, 18 September) "Executive pay and 'golden parachutes' cut by regulatory changes." ABC News, Australian Broadcasting Corporation.

Jensen, M \& Murphy, K (1990) 'Performance pay and top-management incentives' Journal of Political Economy, 98 (2) pp. 225-264.

Johnson, A G (2005) The Blackwell Dictionary of Sociology: A User's Guide to Sociological Language, Blackwell, Malden, MA.

Kahneman, D (2011) Thinking, Fast and Slow, Farrar, Straus and Giroux, New York.

Kruger, J \& Dunning, D (1999) 'Unskilled and unaware of it: How difficulties in recognizing one's own incompetence lead to inflated self-assessments' Journal of Personality and Social Psychology, 77 (6) pp. 1121-1134.

Krugman, P (2002) 'The Class Wars.' New York Times. 20 October.

Krugman, P (2011a) 'Losing their Immunity.' New York Times. 16 October.

Krugman, P (2011b) Why Does Inequality Make the Rich Feel Poorer? New York Times blogs: 12 January. <http://krugman.blogs.nytimes.com/2011/01/12/why-doesinequality-make-the-rich-feel-poorer/\%3E.

Kruse, D (1992) 'Supervision, Working Conditions, and the Employer Size-Wage Effect' Industrial Relations, 31 pp. 2.

Kulich, C, Trojanowski, G, Ryan, M K, Haslam, S A \& Renneboog, L (2011) 'Who gets the carrot and who gets the stick? Evidence of gender disparities in executive remuneration' Strategic Management Journal, 32 pp. 301-321.

Lane, R (2010) The Zeroes, Scribe, Melbourne.

Lazonick, W \& O’Sullivan, M (2000) 'Maximizing shareholder value: a new ideology for corporate governance' Economy and Society, 29 (1) pp. 13-35.

Maiden, M (2003) 'Debunking the myth of the superhero CEO.' Australian. 4 October.

Mankiw, N G (2014) 'Yes, the Wealthy Can Be Deserving.' New York Times. 15 February 2014.

Mann, S (2011) 'Global business chiefs fear poverty could destroy capitalism.' Sydney Morning Herald. 3 December.

Marris, R (1964) The Economic Theory of 'Managerial' Capitalism, Macmillan, London.

Matolcsy, Z P (2000) 'Executive Cash Compensation and Corporate Performance During Different Economic Cycles' Contemporary Accounting Research, 17 (4) pp. 671692.

McIlwraith, I (2010) 'Executive plea: an honest wage for honest work.' Sydney Morning Herald. 28 August.

Mitchell, R (2011) Executive pay increases “unsustainable“, say IoD. BDaily Business Network: 28 November. <http://www.bdaily.co.uk/news/any-other-business/28-112011/executive-pay-increases-unsustainable-say-iod/\%3E.

Murray, G (2006) Capitalist networks and social power in Australia and New Zealand, Ashgate, Aldershot.

Nagel, G L (2007) Persistently Underpaid CEOs and their Influence on Pay Benchmarks. SSRN.

$<$ http://www.fma.org/Orlando/Papers/Persistently_underpaid_CEOs_and_their_influ ence_on_pay_benchmarks.pdf\%3E.

Nienhueser, W (2008) 'Resource Dependence Theory - How Well Does It Explain Behavior of Organizations?' Management Revue, 19 (1+2) pp. 9-32.

Noble Lowndes Cullen Egan Dell (1994) Senior executive remuneration. Industrial Relations Research Series, Department of Industrial Relations, Canberra.

O'Neill, G (2007) 'A Priori Conceptions, Methodological Dogmatism and Theory versus Practice: three reasons why CEO pay research lacks convergence' Corporate Governance: An International Review, 15 (4) pp. 692-700. 
O'Neill, G \& Berry, A (2002) 'Remuneration of Australian executives: A practitioner review' Asia Pacific Journal of Human Resources, 40 (2) pp. 228-245.

Osberg, L \& Smeeding, T (2006) '"Fair" Inequality? Attitudes toward Pay Differentials: The United States in Comparative Perspective' American Sociological Review, 71 (3) pp. 450-473.

Peetz, D (2009) Submission to Productivity Commission Inquiry into Regulation of Director and Executive Remuneration in Australia. Griffith University. Brisbane: May. $<$ http://www.pc.gov.au/_data/assets/pdf_file/0004/89482/sub050.pdf\%3E.

Peetz, D \& Murray, G (2012) 'The Financialisation of Global Corporate Ownership'. in G Murray \& J Scott. Financial Elites And Transnational Business: Who Rules the World? Edward Elgar, Cheltenham.

Pratt, N C (1996) 'CEOs reap unprecedented riches while employees pay stagnates' Compensation and Benefits Review, 28 (5) pp. 20-24.

Productivity Commission (2009) Executive Remuneration in Australia Productivity Commission Inquiry Report, No 49, Melbourne.

Quiggin, J (2006) 'Stories about Productivity' Australian Bulletin of Labour, 32 (1) pp. 1826.

Reilly, K T (1995) 'Human Capital and Information: The Employer Size-Wage Effect' Journal of Human Resources, 30 (1) pp. 1-18.

RiskMetrics Australia (2009) Submission to Productivity Commission Inquiry into Executive Remuneration. Melbourne.

Rubery, J (2005) 'The shape of work and working time in the service sector. A segmentation approach'. in G Bosch \& S Lehndorff. Working in the Service Sector. A tale from different worlds. Routledge, London.

Runciman, W G (1972) Relative deprivation and social justice, Penguin, Harmondsworth.

Ryan, P (2009) pers. comm. email: 4 August.

Schwab, A (2009a) 'Deacons wrong on performance rights.' Crikey. 19 January.

Schwab, A (2009b) 'The Trujillo shambles that haunts Telstra.' Crikey. 14 August.

Sexton, E (2012) 'Please Sir, can I have some less?' Sydney Morning Herald. 18 August.

Shields, J, O'Donnell, M \& O'Brien, J (2003) The bucks stop here: Private sector executive remuneration in Australia. Report to Labor Council of New South Wales, Sydney.

Shields, J, O'Donnell, M \& O'Brien, J (2004) The Bucks Stop Here: Executive Pay and Company Performance. New Economies: New Industrial Relations, Proceedings of the 18th AIRAANZ conference, Noosa, Qld, Association of Industrial Relations Academics of Australia and New Zealand.

Sung, J \& Swan, P (2009) Executive pay, talent and firm size: Why has CEO pay grown so much? Australian School of Business Research Paper No. 2009 FIN 01. University of New South Wales. Sydney: 2 July. <http://ssrn.com/abstract=1420952\%3E.

Svallfors, S (1993) 'Dimensions of Inequality: A Comparison of Attitudes in Sweden and Britain' European Sociological Review, 9 (3) pp. 267-287.

Thornthwaite, L (2010) A critical analysis of the role agency theory plays in executive remuneration. Work in Progress: Crises, Choices and Continuity: Proceedings of the 24th Conference, Association of Industrial Relations Academics of Australia and New Zealand: Refereed Papers, Sydney, [CD] AIRAANZ, .

Tomar, A \& Korla, S (2011) 'Global recession and determinants of CEO compensation: An empirical investigation of listed Indian firms' Indore Management Journal, 3 (2) pp. 11-26.

Tosi, H L \& Greckhamer, T (2004) 'Culture and CEO Compensation' Organization Science, 15 (6) pp. 657-670. 
Tosi, H L, Werner, S, Katz, J P \& Gomez-Mejia, L R (2000) 'How much does performance matter? A meta-analysis of CEO pay studies' Journal of Management, 26 (2) pp. 301339.

Vintila, P (2006) Reach for the stars: CEO salaries and the culture of celebrity in WA's public service, Democracy21: WA Institute for Contemporary Democracy, Working Paper Series No. 1, Perth.

Wachman, R (2009) 'Angry shareholders ambush the top pay bandwagon.' The Observer. 24 May 2009

West, M (2008) 'Golden chutes back in vogue.' Sydney Morning Herald. 27 November.

West, M (2011) 'For whom the sun shines.' Sydney Morning Herald. 12 November.

Williams, A \& Crabb, S (1995) 'Quelling the storm over top salaries' People Management, 1 (5) pp. 22-25.

Yablon, C M (2008) 'Is the Market for CEOs Rational?' NYU Journal of Law and Business, 4 pp. 89-141.

Yernack, D (2005) 'Flights of fancy: Corporate jets, CEO perquisites and inferior shareholder returns' Journal of Financial Economics, 80 pp. 211-242. 